\title{
The Anatomy of the Revenger: Violence and Dissection on the Early Modern English Stage ${ }^{1}$
}

\author{
by Attila Kiss
}

"What brother, am I far enough from myself?" (The Revenger's Tragedy, Vindice, 1.3.1) ${ }^{2}$

The persistent employment of excessive violence on the early modern English stage was studied by Renaissance scholarship for centuries in diverse but rather formal or historicist ways, and this critical focus received no new impetus until the corporal turn in critical theory after the 1980s. Before the poststructuralist, or, more precisely, the postsemiotic and corposemiotic investigations, critics tended to categorize bodily transgression as part of the general process of deterioration that lead to the decadence and all-enveloping perversity of the Stuart and Caroline stage, or they merely catalogued the metamorphoses of iconographic and emblematic elements of the memento mori, the ars moriendi, the contemptus mundi, the danse macabre or the exemplum horrendum traditions through the imagery of violence, mutilation and corporeal disintegration. The reception history of Shakespeare's first tragedy exemplifies the general hostility towards extreme violence, an attitude which was established by the technologies of canon formation in the eighteenth and nineteenth century. Generations of Shakespeare scholars cherished hopes, on account of authorship debates, that one day it would perhaps turn out that Shakespeare had not committed the error of writing the infamous Titus Andronicus, the drama T. S. Eliot considered as one of the stupidest and most uninspired plays ever written. Many interpretations found no clue to the apparently irrational intensification of horror in plays such as The Revenger's Tragedy. Besides claims about the perverse multiplication of evil, the thematic incoherency, the abrupt and amoral ending, the agitated and segmented language, we have such extremes of critical evaluation as that of William Archer:

1 The original version of this paper was presented at the $3^{\text {rd }}$ "Shakespearean Studies in Hungary" conference, organized by the Research Group for Cultural Iconology and Semiography at the University of Szeged in June 2011, and preceded the formal announcement of the foundation of the Transatlantic Network for Emblem Studies. My research has been sponsored by the Janos Bolyai Scholarship of the Hungarian Academy of Sciences.

2 References are to Cyril Tourner The Revenger's Tragedy. ed. Brian Gibbons. The New Mermaids (London and New York, 1989). I do not address questions of authorship here, since they bear no relevance in the present writing. 
I will only ask whether such monstrous melodrama as The Revenger's Tragedy, with its hideous sexuality and its raging lust for blood, can be said to belong to civilized literature at all? I say it is a product either of sheer barbarism, or of some pitiable psychopathic perversion. ${ }^{3}$

The critical discontent, if not hostility, towards the play was well summarized and sanctified by T. S. Eliot in his essay on Tourneur. Just as Hamlet fails to live up to the principle of the "objective correlative," The Revenger's Tragedy also proves to be a failure, since here the object exceeds the play: the drama is the expression of an immature, "adolescent hatred of life." "It is a document on one human being, Tourneur; its motive is truly the death motive, for it is the loathing and horror of life itself." " Of course, together with these condemning tones, there were also critics who pointed out that the medieval morality play as well as the religious, homiletic, and allegorical traditions formed the dramaturgical and philosophical basis of these plays, but the semiotic efficiency of these representations was scarcely studied.

It was the advent of performance-oriented semiotic approaches in the 1970s that brought a new orientation in the explanation of violence. These interpretations restored early modern dramas to the representational logic ${ }^{5}$ of the contemporary emblematic theater, and maintained that verisimilitude or mimetic realism should not necessarily be searched for in English Renaissance dramas, since these plays were purposefully designed for an audience that was ready to decode a multiplicity of emblematic meanings simultaneously. The prevailing emblematic mode of thinking enabled the early modern spectators to establish a symbolical or allegorical interpretation for scenes, events or characters which would prove nonsensical or unrealistic for an audience accustomed to the photographic realism of the later bourgeois theater. ${ }^{6}$ Simultaneously with this emblematic panmetaphoricity, an emerging psychological and representational realism was also becoming more and more powerful, and we have to be aware of the presence of both types of representational logic when we read or stage early modern drama. Glynne Wickham explained the transition from the early modern into the bourgeois theater as a move from the emblematic representational techniques towards a

$3 \quad$ William Archer, The Old Drama and the New (London, 1923), 74.

4 T. S. Eliot Selected Essays. $3^{\text {rd }}$ edition (London: Faber, 1951), 189-90.

5 I am relying on the concept of the representational logic as it has been introduced in the works of Allan C. Dessen. See especially his Elizabethan Stage Conventions and Modern Interpreters (Cambridge: Cambridge UP, 1984).

6 For the emblematic mode of thinking in the English Renaissance, see György Endre Szőnyi, “The 'Emblematic' as a Way of Thinking and Seeing in Renaissance Culture." e-Colloquia, Vol. 1, no. 1 (2003) < http://ecolloquia. btk.ppke. $\mathrm{hu} /$ issues/200301/> 
photographic realism which will become characteristic of the "black box" theatre of nineteenth and twentieth century - at the turn of the sixteenth and seventeenth century, however, we have both:

What we are really confronted with is a conflict between an emblematic theatre - literally, a theatre which aimed at achieving dramatic illusion by figurative representation - and a theatre of realistic illusion - literally, a theatre seeking to simulate actuality in terms of images. ${ }^{7}$

The new performance oriented approaches of the 1970s started to understand the iconographical complexity of violence and horror as a semiotic attempt of the early modern stage to establish a totality of semiosis. Just like the multi-channeled emblem, the English Renaissance emblematic theater also aimed at achieving a complex representation that could perhaps transcend the limits of our knowledge and establish an immediate connection with a more and more questionable and unreachable reality through the multileveled emblematic representations. This semiotic endeavor was a reaction to the epistemological uncertainties of the age, the general crisis in knowledge which, alas, also characterizes our world of the postmodern. These interpretive approaches have helped us understand the way theatrical effect emerged on the early modern stage, and they have established a general awareness in critics and readers that we have to direct these dramas in our imaginative staging.

Part of the persistent metatheatricality of early modern plays is a selfreflexive ostentation of their nature as designed spectacle. "See here my show, look on this spectacle." (4.4.89) ${ }^{8}$ This is how Hieronimo, "Author and actor in this tragedy" (4.4.147) presents the staging of the climactic, final ostentation of the human body in the penultimate scene of The Spanish Tragedy. His words are emblematic of the most important endeavor of English Renaissance theater, which was to produce a spectacular show that foregrounds questions of the human condition within the context of a quite unstable and controversial, new model of human subjectivity. However, when it is not witnessed in the playhouse, it takes serious imaginative effort and visualization by the reader of Kyd's play to realize the weight of this scene. We miss the very efficiency of the stage tableau, performance oriented approaches warn us, if we do not insert it into the representational dynamics of the stage. Horatio's body, carried on stage quite ritualistically by a

$7 \quad$ Glynne Wickham Early English Stages. 1300 to 1600. Volume Two 1576 to 1660, Part One (New York: Columbia UP, 1963), 155.

8 References are to Thomas Kyd The Spanish Tragedy. ed. J. R. Mulryne. The New Mermaids (London and New York, 1989). 
mourning patriarch, is a "butchered" cadaver well in the process of decomposition, and we should smell this when we read the play.

Thus, violence and horror, transgression and excess, came to be observed in Renaissance scholarship as perhaps the most important constituents in the imagery and representational repertoire of early modern tragedy. Although, as has been argued, the abundance of corporeal representations was studied within rather formal interpretive frameworks until the advent of poststructuralist approaches, after the 1970s the semiotic analysis of stage - audience interaction and representational efficiency opened up the scene for a more contextualizing cultural iconology and a psychoanalytically informed investigation of the effects of horror. Since then, the interpretive efforts accounting for the imagery and dramaturgy of violence have argued that the transgression of the body was not only an emblematic mode of expression that relied on numerous iconographic traditions inherited from the middle ages, and it was more than a representational technique which aimed at producing a polysemous totality of theatrical symbolism. The performance oriented semiotic approaches have explicated how the representational logic of the English Renaissance emblematic theater gave rise to various techniques that thematized the problems and antagonisms of the constitution of early modern subjectivity. The postsemiotic scrutiny of these representational techniques has revealed that the violence and transgression which concentrated upon the dissected, tortured, anatomized and mutilated human body on the Tudor and Stuart stage did not merely function to satisfy the appetite of a contemporary public that demanded gory entertainment in the public theater. These representational techniques of dissection and violence participated in a general epistemological effort of early modern culture to address those territories of knowledge that had formerly been hidden from public discourses. The human body, the temple of divine secrets and the model of universal harmony, was undoubtedly one of the most intriguing of such territories. 


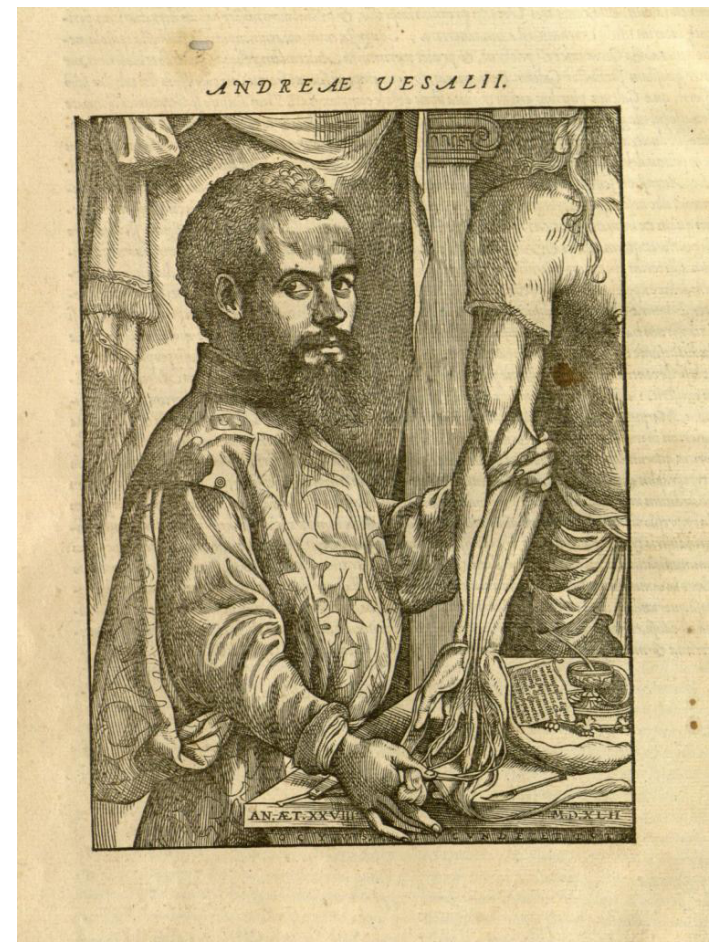

1. Portrait of Andreas Vesalius, the Flemish anatomist who revolutionized the practice of dissection, from his De Humani Corporis Fabrica (1543). Unlike in earlier representations of the public autopsy, the anatomist here is in an almost intimate connection with the cadaver. The attitude so consciously displayed by Vesalius is emblematic of the early modern anatomical curiosity. (Courtesy of Somogyi Library, Szeged)

The corporeal turn has directed the focus of critical attention to the fact that transgression and violation, as represented on the early modern stage, concentrate with anatomical precision on the body of the human being. Poststructuralist theories have helped us understand how the foregrounding of abjection and disintegration produces an effect in the psychosomatic structure of the receiver, which effect largely accounts for the career of these plays. However, it has not been left unnoticed either that the early modern corporeality and inwardness emerge not only in gruesome dramatic literature and on the public stage, but in a multiplicity of aesthetic and social discourses as well, and these discourses all appear to engage in a dissective effort. Sir Philip Sidney, for example, relies on an anatomically penetrating bodily imagery when commenting on the uses of tragedy: 
So that the right use of Comedy will, I think, by nobody be blamed, and much less of the high and excellent Tragedy, that openth the greatest wounds, and showeth forth the ulcers that are covered with tissue ...?

There is an obsession in the English Renaissance with the skin that covers the depth of things and hides the structuration of some innermost reality from the public eye. Transgression in early modern tragedy is very often not merely a violation of social or political standards and laws, but primarily a transgression that penetrates the surface of things in an epistemological attempt to locate the depth behind the surface. Of course, this obsession had its modes of expression as well as its regulatory forces of surveillance and containment, but the skin of the human body surely became understood as a general metaphor of the new frontier that started to be tested in the process that I call the early modern expansive inwardness: a more and more penetrative testing of the inward dimensions of the human body and the human mind.

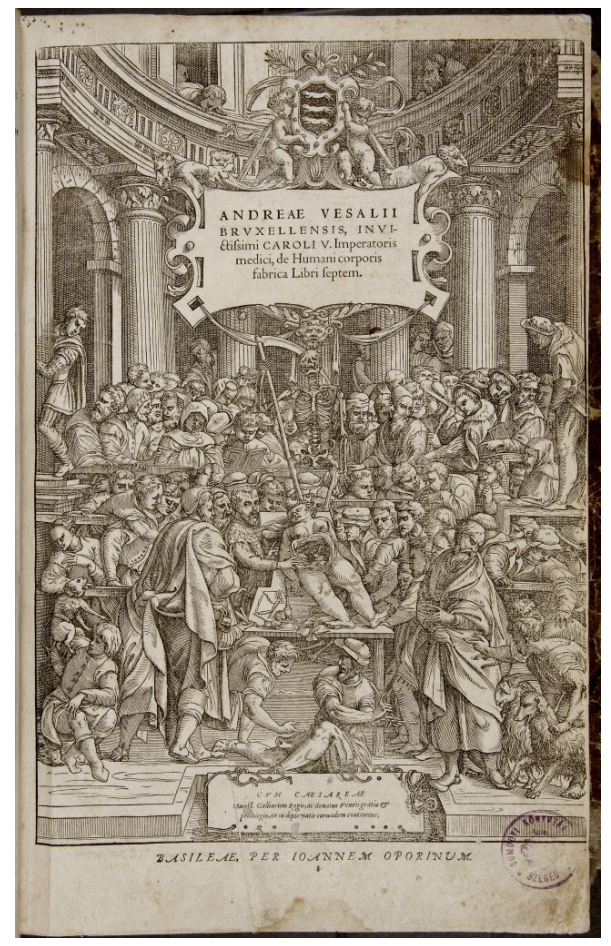

2. The title page of De Humani Corporis Fabrica. The powerful verticality of the woodcut is clearly reminiscent of the idea of the Great Chain of Being, the secrets of which are now being tested by the new methods of anatomy that penetrates the skin of the body as well as the existing surfaces of knowledge. In the focal point, where the diagonals of the composition of characters intersect, we have Vesalius's hand resting on the peeled off skin of the cadaver. (Courtesy of Somogyi Library, Szeged)

$9 \quad$ Sir Philip Sidney, Selected Writings, ed. Richard Dutton (Manchester and New York: Fyfield Books, 1987), 124. 
Traveling and exchanged body parts, dismemberment, dissolution by poison, self-beheading, torture, macabre spectacle, madness and terror anatomical images of the body recur in English Renaissance tragedies from The Spanish Tragedy and Titus Andronicus to The Revenger's Tragedy and The Broken Heart. The popularity of the public autopsy and the anatomical theater was second only to the public playhouse by the beginning of the seventeenth century. The lesson that the emergent modern cultures of Europe learned from such anatomies was that the human body is something uncontrollably heterogeneous and difficult to contain, and this is why the corporeality of the subject became the primary object of ideological suppression. After the anatomical discourses that penetrated the surfaces of the human body with relentless effort in the Renaissance, the human corpus had to be covered up again totally by a new ideological skin, that is, the discourses of rationalism and the newly fabricated Cartesian ego. This commences, however, only in the eighteenth century.

Naturally, the body had always been in the forefront of general human interest. Death and the body have become inseparably intertwined in the history of western civilization, and this union, which marginalized the corporeal and tried to eternalize some other constituent of the subject as incorporeal and thus immortal, resulted in the suppression and demonization of the body. The body, however, has been held accountable not only for mortality, but everything which is beyond the capacity of the reasoning mind or the rationalizing ego to control - transgression, sexuality, heterogeneity, incalculable acts and thoughts of the subject. The early modern period was an age of corporeal experimentation, but this inwardness is then followed by the advent of a new bourgeois ideology. By the time the dominant discourses of the Enlightenment settle in, the body becomes articulated as the ultimate target of social censorship and individual self-hermeneutics. Consequently, nothing could be more fascinating than the re-emergence of this corporeality in the cultural imagery of the postmodern. As the thought of death is in continuous metamorphosis with the new technologies of cloning, gene manipulation and hibernation, in the same manner the body reappears from under the skin of ideologically determined meanings as a site of epistemological curiosity, and a new postmodern inwardness directs the public attention towards the interiority of the subject. Fantasies of corporeality, which used to be marginalized and suppressed, are now infiltrating the practices of social spectacle. ${ }^{10} \mathrm{I}$ propose that it is perhaps

10 The most complex and spectacular example of this postmodern anatomical interest is the hugely successful traveling exhibition invented, organized and orchestrated by the German Gunther von Hagens. His Body Worlds has attracted tens of millions of people to see his specially plastinated human corpses that reveal the several layers in the structuration of the human body in often shocking or grotesque positions. See http://www.bodyworlds.com/en.html. The success and influence of this highly theatricalized exhibition was further intensified by the public autopsies von Hagens has performed, and its influence is indicated by the 
exactly through this postmodern renaissance of anatomy that we can understand better the function and representational logic of bodily transgression on the English Renaissance stage.

The postmodern interest in the bodily constitution of the subject and the corporeal foundations of signification has been necessitated not only by the critique of phenomenology and the early findings of psychoanalytically informed postsemiotic theories, but just as well by the growing presence of the anatomized and displayed body in the practices of every-day life. The phenomenon that perhaps best characterizes the body in the cultural practices of postindustrial societies is the way it has been subjected to a process of anatomization and inward inspection. Anatomy has become an all-embracing and omnipresent constituent of the postmodern cultural imagery, and its growing presence has saturated not only the urban spaces where body representations are disseminated, but also the multiplicity of critical orientations that have been aiming at accounting for this postmodern interest and investment in the corporeal. The body is endlessly commodified, interrogated, dissected and tested in ways that are very often reminiscent of the early modern turn to the interiority of the human being. The intriguing private body has, once again, become a primary site of social fantastication.

As much critical literature has argued recently, the postmodern scrutiny of the body is comparable to the early modern anatomical turn towards the interiority of the human body. ${ }^{11}$ In both historical periods the body is a territory of the fantastic, an epistemological borderline, a site of experiments in going beyond the existing limits of signification. In short, postmodern anatomies are grounded in an epistemological crisis which is very similar to the period of transition and uncertainty in early-modern culture, when the earlier "natural order" of medieval high semioticity started to become unsettled, and the ontological foundations of meaning lost their metaphysical guarantees.

As the various images of death in the memento mori and ars moriendi traditions functioned in early modern culture as agents of Death the Great Leveler, so the corpses in the postmodern anatomy exhibition may unveil the sameness of the subject and the Other by the ostentation of that which is other in both: the corporeal, bodily foundations of our subjectivity. In this respect, postmodern anatomy goes beyond a mere catering for the sensationalism and curious appetite of the general and alienated masses of consumerism.

fact that its rivals have also appeared on the market of postmodern social spectacle, for example the show Bodies: The Exhibition. See http://www.bodiestheexhibition. $\underline{\mathrm{com} /}$

11 “... early moderns, no less than postmoderns, were deeply interested in the corporeal 'topic'." The Body in Parts: Fantasies of Corporeality in Early Modern Europe, ed. David Hillman and Carla Mazzio (London and New York: Routledge, 1997), Introduction, xii. 
I maintain, in light of the above considerations, that the subject of present day culture is enticed to bear witness to its own otherness and, thus, to its sameness with the Other in the cultural imagery of anatomization. In other words, public anatomy establishes an effect in which the subject is compelled to experience and see the strong materiality into which its own subjectivity is inscribed: the flesh behind the face, the body behind the character, the tongue behind the speaker. This is the very materiality that we are also compelled to bear witness to in English Renaissance tragedy.

From this new postmodern affinity towards the protomodern anatomizing habits of mind, I would like to turn back to the early modern stage in order to demonstrate through textual examples how the dissective epistemological curiosity of early modern culture manifested itself in ways that were constitutive of the dramaturgy of English Renaissance tragedy. The idea of the tongue behind the speaker probably urges us all to think of Hieronimo in The Spanish Tragedy who, in a self-dissecting and mutilating act, bites out his own tongue in order to close up all secrets and stratagems in himself, and thus secures a final authorial control over the happenings of the revenge tragedy.

\section{Indeed}

Thou mayest torment me as his wretched son

Hath done in murd'ring my Horatio;

But never shalt thou force me to reveal

The thing which I have vowed inviolate.

And therefore, in despite of all thy threats,

Pleased with their deaths, and eased with their revenge,

First take my tongue, and afterwards my heart.

$(4.4 .184-191)^{12}$

The concept of the body behind the character will make us think of Lavinia who becomes a living emblem of woe in Titus Andronicus, and incites old Titus to embark on a peculiar semiotic endeavor to devise a new alphabet, a different language that could interpret between Lavinia's tongueless, handless and ravished body and the world.

Hark, Marcus, what she says;

I can interpret all her martyr'd signs;

[...] Thou shalt not sigh, nor hold thy stumps to heaven,

Nor wink, nor nod, nor kneel, nor make a sign,

But I of these will wrest an alphabet

And by still practise learn to know thy meaning.

12 References are to William Shakespeare The Riverside Shakespeare. Ed. Blakemore Evans (Boston: Houghton Mifflin Company, 1972). 
We will of course also think of Hamlet, where we find an interesting typological structure if we are careful enough to observe the anatomical imagery of corporeality in the play. Immediately after his famous outcry about the melting of flesh, Hamlet builds up a description of his mother's face and this image will inevitably be informed by the idea of decay and decomposition which had just preceded it.

$\mathrm{O}$, that this too too solid flesh would melt

Thaw and resolve itself into a dew!

[...] That it should come to this!

But two months dead: nay, not so much, not two:

So excellent a king; that was, to this,

Hyperion to a satyr; so loving to my mother

That he might not beteem the winds of heaven

Visit her face too roughly.

[...] Ere yet the salt of most unrighteous tears

Had left the flushing in her galled eyes,

She married. O, most wicked speed, to post

With such dexterity to incestuous sheets!

It is not nor it cannot come to good:

But break, my heart; for I must hold my tongue.

(1.2.129-159)

The face, the eye, the heart and the tongue function figuratively here, but they are also examples of how English Renaissance tragedy displays a postmodern kind of awareness about the materiality of language that is always at work as an agency beyond the human being's capacity to control it. What is said very often becomes performatively and uncontrollably active later on in these plays, and it takes just a small step to move from figurative metaphoricity into corporeal action, from fantasized decay into rotting death. Again, we have to be aware of the theatrical space, since the actual method of stage performance can foreground a connection between the above soliloquy and Hamlet's meditation upon Yorick's remains later - a connection which is a potential in the text and can be realized if the actor uses, for example, the same movements of the hand when he imaginatively portrays his mother's face and when he touches the jester's skull. Hamlet's imaginative anatomization of the skull functions as an antitype to the earlier meditation on flesh, face and tongue, and the typological link is established retrospectively if the actor performs similar gestures in the two scenes.
Alas, poor Yorick!
$[\ldots]$ Here hung those lips that I have kissed I know
not how oft. Where be your gibes now? your 
gambols? your songs? your flashes of merriment, that were wont to set the table on a roar? Not one now, to mock your own grinning? quite chap-fallen?

Now get you to my lady's chamber, and tell her, let her paint an inch thick, to this favour she must come; make her laugh at that.

The extreme visions or fantasies of a tongueless Hieronimo, a decaying Horatio, a Faustus torn apiece by devils, a mutilated Lavinia, a lipless Yorick, an anatomized Regan - the examples could be listed endlessly, and they all mark the intensive anatomization of the body in English Renaissance tragedy, a transgressive representational technique that brought the early modern spectator face to face with its own innermost Otherness, the frontier of (new) knowledge.

Of all these anatomical plays, I would now like to turn to The Revenger's Tragedy to show how the play mobilizes a set of well known but already half-exhausted iconographic traditions to establish an effect which is a special mixture of moralizing and ridicule. This late revenge tragedy by Middleton (or Tourneur?) is a mature piece in the tradition of a special double anatomy in early modern revenge tragedies. This anatomy is double in two different ways: it is operational not only in the sense that the tragedies foreground the systematic dissection of both the mental and the physiological potentialities of the human being. Within the dramaturgy of these tragedies, the anatomization of body and mind is accompanied by a special double anatomy of and by the revenger. On the one hand, an anatomy of adversaries is staged by the revenger, but the revenger's anatomy lesson at the same time gradually turns into his own selfdissection, stripping his personality bare naked to the point of self-loss. This point of disintegration and loss is seemingly negative and harmful, but in fact it is the condition in which the revenger really becomes able to act out and master those roles which had been necessitated by the taking up of the task of revenge. "Man is happiest when he forgets himself." (4.4.85) - says Vindice, and the explanation for this seemingly paradoxical ars poetica is that, in order to demonstrate and perform the typically Neo-platonic capacity of the human being to go through endless metamorphoses, the revenger has to master the art of self-loss, a self-anatomy which then enables the revenger to carry out the anatomy of his enemies. This art of self-loss is performed in The Revenger's Tragedy through a series of shockingly spectacular anatomical twists.

Renaissance scholarship has long held the beginning of The Revenger's Tragedy as a peculiar example of ambivalence. Vindice appears on stage with a skull in his hand as the presenter of a play that later turns out to be his own devise, and the metatheatrical framework is already anticipated by the puppet-show-like presentation he produces when introducing the characters. This initial scene provides the spectators 
with a synthesis of memento mori and contemptus mundi traditions with the obligatory iconographic accessories. We have here the emblematic skull, already a commonplace so widespread that aristocrats in Jacobean England had jewelry with skull shaped figures, ${ }^{13}$ as well as characters presented like cadavers that are now enlivened by the commanding words of Vindice, the master of puppets in his net of intrigues. ${ }^{14}$ We listen to the first few lines and the atmosphere will unmistakably urge us to associate the scene with the danse macabre tradition.

Anatomy also makes its powerful appearance already in this prologue, since even a superficial count will come up at least with fifteen images of human corporeality in Vindice's opening soliloquy.

Four ex'lent characters! - Oh that marrowless age

Would stuff the hollow bones with damned desires, And 'stead of heat kindle infernal fires

Within the spendthrift veins of a dry duke, A parched and juiceless luxur! Oh God! one That has scarce blood enough to live upon, And he to riot it like a son and heir?

Oh, the thought of that

Turns my abused heart-strings into fret.

Thou sallow picture of my poisoned love, My study's ornament, thou shell of death,

Once the bright face of my betrothed lady,

When life and beauty naturally filled out

These ragged imperfections;

When two heaven-pointed diamonds were set

In those unsightly rings - then 'twas a face

So far beyond the artificial shine

Of any woman's bought complexion $[. .$.

[...] Be merry, merry;

Advance thee, $\mathrm{O}$ thou terror to fat folks,

To have their costly three-pil'd flesh worn off

As bare as this $[\ldots]$

13 Phoebe S. Spinrad The Summons of Death on the Medieval and Renaissance English Stage (Ohio State UP, 1987).

14 Fort he stage employment of these dramatic and iconographic devices, see: Douglas Bruster. "The Dramatic Life of Objects." In Gil Harris and Natasha Korda (szerk.) Staged Properties in Early Modern English Drama (Cambridge, 2002); Graham Holderness. "I covet your skull': Death and Desire in Hamlet." Shakespeare Survey Vol. 60 (Cambridge UP, 2007). 
Several interpretations in the recent trend of problematizing early modern corporeality and inwardness have dealt with the emphasis on the dead body and the skull in The Revenger's Tragedy. Susan Zimmerman argues that the ambiguous status of the cadaver as something in between the animate and the inanimate was an important element of English Renaissance popular beliefs, and the ideas about the latent harmful or even contagious powers of the corpse inform the presentation of Gloriana's skull and Antonio's wife. Writing about the "grotesquely outrageous humour" that is so characteristic of many tragedies of the period, Zimmerman contends that:

[...] the 'graveyard ambience' of these plays proceeds in part from their appropriation of popular notions of the corpse, particularly the long tradition of its mysterious, semi-animate status. In Middleton's play the shifting symbolic values of Gloriana's skull serve to activate, as it were, the latent power of her original corpse; and the newly dead and eroticized body of Antonio's wife evokes the preoccupation in Renaissance iconography with the sexual/reproductive power of the female corpse, seen in phenomena as disparate as the danse macabre and the illustrations of anatomical treatises. ${ }^{15}$

Hillary M. Nunn in her powerful book on dissection and spectacle excels in mapping out the various connections between early Stuart theatrical and anatomical practices, and she also draws attention to Vindice's obsession with the skull which he employs as if it was still a living person, a fully animate agent. As Nunn puts it:

[...] for Vindice the bony head remains the indisputable embodiment of his dead beloved's spirit, as well as his exclusive property. Holding such conversations with Gloriana's skull evidently proves a habit with Vindice, for when his brother Hippolito comes upon the scene, he wearily asks why Vindice is “'Still sighing o'er death's vizard (1.1.49). ${ }^{16}$

I cannot but fully agree with these observations, but I also think they fail to observe that Vindice the presenter-revenger literally dissects the verbally built up and visualized image of Gloriana's head and face, and finally arrives at the bare skull,

$15 \quad$ Susan Zimmerman The Early Modern Corpse and Shakespeare's Theatre (Edinburgh, Edinburgh University Press, 2007), 129.

16 Hillary M. Nunn Staging Anatomies: Dissection and Spectacle in Early Stuart Tragedy (Ashgate, 2005), 142. 
only to set it into its lethal motion. It is the agency of this skull that will generate the anatomization and death of the royal members in the corrupt court. As a matter of fact, Vindice presents a public and retrospective autopsy of Gloriana which sets up a typological agency in the tragedy, since it foreshadows that disintegration which awaits the Duke and his allies. Thus, Vindice's prologue works as the type of the play as antitype. Vindice functions as "author and actor in this tragedy," in the very same way Hieronimo did in the metatheatrical framework of The Spanish Tragedy, and he initiates the dissective work of the skull by rolling it into the world of the plot he intends to direct. The scene is certainly reminiscent of Hamlet's appearance with the skull, and it is also an iconographically exuberant melting pot of a number of commonplace moralizing traditions. To further intensify the effect of the scene, we are shocked by the revelation that the skull in the revenger's hand belongs to his former lover. This shock then definitely turns into some uncomfortable laughter when the spectator comprehends the complexity of the situation: Vindice must have taken careful and professional steps to prepare the skull of the long-diseased Gloriana in order to transform it, first, into an ornament of his study, and now the emblem of the anatomical agency in his play.

What is it, then, that still saves The Revenger's Tragedy from becoming a cheap parody or burlesque of the traditions and representational techniques that had lost their power by the beginning of the seventeenth century? My contention is that the representational efficiency of the play is a result of its systematic staging of that kind of transgression which moved into the forefront of public attention with the advent of early modern public autopsy. Bodily transgression in Middleton's play is systematically anatomical and it exposes the early modern spectator to the questions of its own constitution, questions that were becoming more and more acute in the epistemological crisis of the period. These anatomical transgressions add a new dimension, a new depth to the memento mori in this revenge tragedy. The foregrounding of the human being's fallibility and corporeality reminds the subject not only of its mortality and the approaching time of death, but of its corruptible, material origin as well, of the Other, the cadaver inside. Huston Diehl argues that early modern drama, just like its medieval origin the morality play, was supposed to "put us in remembrance,", but remembering was becoming exceedingly problematic at the time of a new, reformed theology in Renaissance England. Michael Neill contends that revenge narratives make an attempt to process the traumatic effect of the abolition of Purgatory and intercession, ${ }^{18}$ and

17 Huston Diehl. "To Put Us in Remembrance: The Protestant Transformation of Images of Judgment." In David Bevington et.al. Homo, Memento Finis: The Iconography of Just Judgment in Medieval Art and Drama (Kalamazoo: Western Michigan University, 1985), 179-208.

18 “...revenge narratives [are] a response to particularly painful aspect of the early modern reimagining of death - the wholesale displacement of the dead 
I believe another important element of this thanatological crisis was the newly discovered corporeality of the subject, which the audience of the Renaissance emblematic theater was constantly put "in remembrance of." This corporeality is already much more than the medieval moralizing on the dust that we will all return to. It establishes the effect that can be best characterized by the term Vindice himself employs at the end of his opening soliloquy: terror.

"Advance thee, O thou terror to fat folks." (1.1.45) - thus the revenger commands the skull, the master agent of the play, and terror is the proper word here, since the agency of the skull disseminates the latent potentiality of death in the entirety of the play, and, theatrically directed by Vindice, it will truly peel off skin and flesh during its anatomical movement.

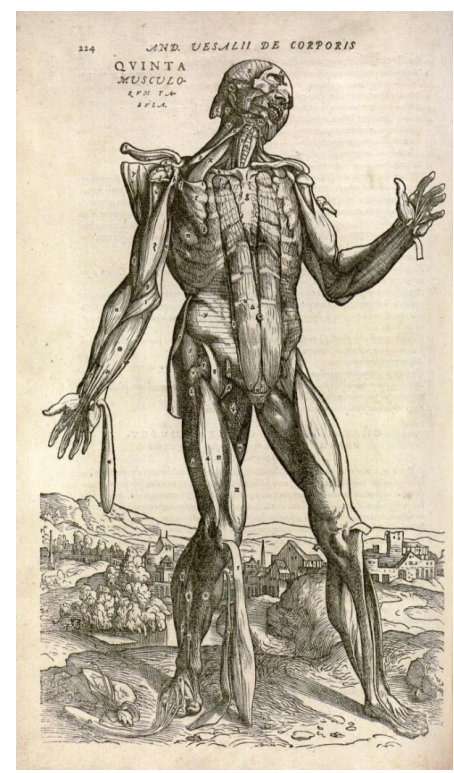

3. "To have their costly threepil'd flesh worn off / As bare as this." - Vindice instructs the skull to engage in an operation that is quite identical with the dissective work of early modern anatomy, as demonstrated in a plate from De Humani Corporis Fabrica. (Courtesy of Somogyi Library, Szeged)

This omnipresence of death had of course been focal in medieval drama and iconography as well, and the symbolical skeleton with the scythe peeped and sneaked into the rooms and bedchambers of mortals at the most unexpected hour, but English Renaissance tragedy goes beyond this iconography, and systematically thematizes the skeleton, the skull within us. The adventures of the skull in The Revenger's Tragedy set up a peculiar economy of terror through the anatomical

from their familiar place in the order of things by the Protestant abolition of purgatory and ritual intercession. Revenge tragedy exhibits a world in which the dead, precisely because they are now beyond the help of their survivors, have become practically insatiable in their demands upon the living." Michael Neill Issues of Death. Mortality and Identity in English Renaissance Tragedy (Oxford UP, 1998), 46. 
imagery, because they implant in the spectator a continuous awareness of his or her own anatomical reality, the skull beneath our face.

After the anatomization of Gloriana and the introduction of her skull in the first scene, the second anatomical twist in the play comes with the first spectacle of revenge carefully designed and performed by the protagonist. The sophisticated and prolonged staging of the killing of the Duke in the dramaturgical turning point of the play is also meticulously anatomized by Vindice. The Duke is not simply tortured and murdered - the scene is designed in a way so that the totality of the human being is literally dissolved. Poison is perhaps the most frequently recurring element in the imagery of the play, and poison is employed on Gloriana's skull to launch the process that turns the face of the Duke into a rotting skull, the thing he had turned Gloriana into several years earlier. As the teeth of the Duke are being eaten out by the poison, his tongue is nailed to the ground, and his eyes are being pushed out by the revengers. "The very ragged bone has been sufficiently revenged." (3.5.153-54) - proclaims Vindice, but the process also has to penetrate the enemy's soul, so the Duke is forced to bear witness to how his bastard son cuckolds him with his wife in the neighboring chamber.

Puh, 'tis but early yet; now I'll begin

To stick thy soul with ulcers, I will make

Thy spirit grievous sore: it shall not rest,

But like some pestilent man toss in thy breast. Mark me, duke, Thou'rt a renowned, high, and mighty cuckold.

$$
\text { (3.5.170-174) }
$$

The ulcers Vindice intends to implant in the Duke's soul curiously echo Sidney's conception about the power of tragedy that "openth the greatest wounds ... and showeth forth the ulcers" - mental and psychological as well. Vindice performs a double anatomy of body and soul here, and the scene foregrounds an awareness of the psychosomatic complexity of the human being. The unity of the corporeal and the mental is exposed here to a slow process in which the revenger-anatomist tries to grasp the moment of transition from life to death, to reveal the mystery that was also the objective of public autopsies in the Renaissance anatomy theatres. We might comprehend the anxiety aroused by the scene even better if we consider that the roles of the executioner and those of the anatomist were not so clearly distinct as we would perhaps presume today. As Jonathan Sawday explains:

In the past, however, such a finely drawn distinction between the art of the healer and the skills of the executioner did not exist. On the contrary, early-modern understanding of the human body if firmly anchored in the willingness of the body's investigators to participate in the execution 
process in claiming for the anatomy table the bodies of the executed. [...] there was very little distance between the ritual of execution and the opening of the body to knowledge. This confusion of roles, or (less charitably) this assumption of a dual role on the part of the anatomist-executioner was of crucial importance to the rise of anatomical science in the Renaissance. ${ }^{19}$

With his initial metaphorical dissection of Gloriana, his persistent effort to wear off the skin and flesh of the members of the corrupt court, and his relentless self-examination in the process of getting as far from his original self as possible, Vindice as arch-revenger in the play's web of revenges outdoes the others because he is capable of fully identifying with the roles he strives to master. In his capacity as executioner-anatomist and metatheatrical master of revels, he opens up the ulcers in the society that surrounds him as well as those in his own soul and mind, but this process inevitably leads to his total self-dissection. He becomes a living emblem of the Neo-platonic teaching about the potential in the human being to change, to go through transformations. It is typical of early modern contrariety, and especially of revenge tragedies that this art of metamorphosis does not culminate in a final Renaissance selfrealization, because the roles that the revenger assumes entirely consume his original personality. Vindice's revenge strategies go hand in hand with his self-anatomy which has its concluding act in a final anatomical twist, in his own disassemblement. The revenger departs from the world of the play in excellent spirits although he is to be executed, because he realizes that, with the completion of the task of revenge, with no more roles to play and no original identity to return to, there is nothing left that would legitimate his existence.

Violence in these scenes, as in English Renaissance tragedy in general, is thus never for its own sake. The repeated anatomical turning points in The Revenger's Tragedy and in early modern English revenge plays are difficult to comprehend without a knowledge of all the emblematic codes that the plays simultaneously employ and interrogate. At the same time, we also have to bear in mind that the excitement and tension that emerged in this emblematic theater were, to a large extent, grounded in the early modern anatomizing curiosity, the relentless investment in an inwardness that informed the representational logic of the English Renaissance stage.

\author{
Attila Kiss \\ University of Szeged \\ Department of English \\ Research Group for Cultural Iconology and Semiography
}

19 Jonathan Sawday The Body Emblazoned. Dissection and the Human Body in Renaissance Culture (London and New York: Routledge, 1995), 79-80. 